\title{
Analysis of Effectiveness of Executive Trainees' Training Programme with a Special Reference to Academic Parameters
}

\author{
Dr. Neeraj Kumari \\ Department of Management, Faculty of Engineering \& Technology \\ Manav Rachna International University, Faridabad, India
}

Received: January 27, 2017 Accepted: February 27, 2017 Published: March 20, 2017

doi:10.5296/jad.v3i2.10654 URL: https://doi.org/10.5296/jad.v3i2.10654

\begin{abstract}
The study aims to analyze the efficiency of training programme at POWERGRID Corporation of India Limited with a special reference to academic parameters, and to find out if there is any improvement required to make the training programme more effective. Descriptive research design has been used in the study. The sample size is 127 . A survey was carried out to obtain the feedback of the trainees. About $93.70 \%$ of the respondents are of the view that initial class room training is sufficient. About $96.06 \%$ of them are of the view that the post On Job Training (OJT) is constructive and indispensable. About $89.76 \%$ of the respondents said that the rotational OJT is valuable. The findings show that the trainees were satisfied up to a large extent with the training programme. To improve the training programme; module should be updated on yearly basis, period of training should be less than one year and there should be more industry visits on time to time basis.
\end{abstract}

Keywords: development, knowledge, performance, placement, skills 


\section{Al Macrothink}

\section{Introduction}

The study is based on the Training and Development Programme of ET'S (Executive Trainees). The study is conducted on the overall development of ET'S after the final placement in POWER GRID. Executive Trainees are recruited / selected in POWERGRID through a rigorous process of written test followed by Group Discussion, Interview and medical fitness tests.

On selection, the newly recruited Executive Trainees are put to one year comprehensive training programme. The prescribed one year training programme has been designed to guide the young executives in transforming their academic knowledge into practical applications to suit to POWERGRID needs. The training programme has a balanced usage of technical, management and soft skills inputs to give them the foundation, industrial visits to acquaint them of the latest practices in the industry and on the job training to give a practical exposure to all facets of POWERGRID working, where they get chance to groom themselves to become the top Power Professional.

After selection, the recruited Executive Trainees are put to one year Training Programme:

Table 1. Break-up of one year Training Procedure

\begin{tabular}{lll}
\hline S. No. & Particulars & Duration \\
\hline 1 & Class-room Training & $4^{1 / 2}$ Months \\
2 & On the Job Training & $6^{1 / 2}$ Months \\
3 & Second phase of class-Room training & 1 Month \\
\hline
\end{tabular}

In this way they also get an opportunity to meet representatives of various department and regions. Induction process is not a one-off process they will be able to benefit from this development opportunity throughout your career either through formal structured programmes or events or from informal activities.

After second phase of overall Training, they have to submit their report at the time of FINAL-APPRAISAL and according to the overall performance of the Trainees the held Committee rates them and on the basis of merit their posting are being decided. POWERGRID provides a learning teaching and research environment that is second to none and there is only one way of achieving it which is through the quality and commitment of the POWERGRID.

Corporate success depends upon having and retaining talented people. This is true today as it has always been. The shortage of such people is widely accepted and training, at long last, is beginning to be recognized as part of the solution and hence the total investment in training is on the rise. This is true for all organizations. There really is no alternative than to make sure that human skill so vital to the corporate success are recognized, harnessed, developed and 
suitably maintained. Training is not however, one 'one-off' investment. It is a continuing investment. Not only is it needed to create the skilled workforce, but also maintain the high levels of skills demanded by the ever changing, highly dynamic work place.

The return on investment on HRD is still controversial in view of the time variable in achieving the desired change and effectiveness in the employees. The top management looks at the loss and profit equation for any activity. It is interested in the benefits to the organization in the terms of increased productivity, increased profitability, reduction in wastage etc in return for investment in training. Hence, evaluation of training programmers and introduction of the necessary corrective measures also assumes considerable significance. Training is the most important function that contributes directly to the development of human resources. If human resources have to be developed, the organization should create conditions in which people acquire new knowledge and skills and develop healthy patterns of behavior and styles. One of the main mechanisms of achieving this environment is training.

\section{Review of Literature}

Pillania (2014) it was concluded the state of teaching, research, training and consultancy is not good enough within the business schools in India. The findings are not encouraging and Indian business schools need to give more attention to the subject of green management both in theory and practice. Malik (2009) Employee turnover, competitive strategy, client specifications and quality management systems were important factors in shaping the nature and extent of training. The temporal dimension of the process was also significant in influencing volume of training. The study also found that learning and development were inextricably intertwined with its operations management, as against a firm's HR infrastructure. Fullerton (2011) an awareness of time contexts and complex change is essential, so too is an appreciation of primary sources. Reading the present into the past (anachronism) is to be avoided, and the interpretation and explanation of events are essential to good history. Dana (2001) Entrepreneurship creates wealth and reduces unemployment. Entrepreneurs contribute to industrialization as well as to economic growth; they improve living standards and tax revenues from their enterprises contribute to a nation's treasury. Not surprisingly, then, governments have been spending considerable sums trying to create entrepreneurs. Wiese (2006) the severe shortage of black chartered accountants (CAs) in South Africa highlights the need for equity in the development of future accountants. However, despite the transformation initiatives that had already been introduced by then, at the end of 2001, black CAs were still grossly underrepresented in the membership of the South African Institute of Chartered Accountants (SAICA). Furthermore, black trainee accountants' still experienced cultural and social alienation, hostility and mistrust in their ability, resulting in their not reaching their full potential. Results show that black accountants are still a minority in the accountancy profession. Baum (1991) the recruitment of quality management is an issue of paramount importance to the hotel industry in all major tourism destinations and the educational sector is the main provider of personnel with the appropriate competences. Ensuring a close match between the goals of educational programmes and the demands of industry is an ongoing issue in the hotel sector as it is in other industries. A comparison between the prioritized expectations of American and British general managers with respect 


\section{Macrothink

to the competences that they require of graduate recruits shows that while major similarities are evident, significant differences also appear, especially in the greater priority given by British managers to competences in the legal/ regulatory domain, including hygiene, health and safety. Tsang (1999) Discusses the methodological issues in costing two common types of vocational training programmes: institutional vocational training and enterprise-based vocational training. Points out that the survey/interview approach should be used to collect data from institutions instead of from the government in costing institutional vocational training, and that more frequent use should be made of the case-study and survey methods in costing enterprise-based vocational training. Coates (1990) Training of managers as trainers in Africa and South East Asia to meet the special needs of banks in developing countries is described. Specific attention is given to the learning process. There is a need to focus on the actuality of the working environment of training programme participants and to make learning action centered.

\section{Methodology}

\subsection{Objectives}

- To analyze the efficiency of Training programme with a special reference to academic parameters.

- To find out if there is any improvement required to make the training programme more effective.

\subsection{Scope of the Study}

The study will help giving some suggestions for making the present training and development system more effective. It would also help in identifying the training and development needs present among the Executive Trainees. Moreover the report will help to make the decision of adding/deleting any important Module Programme

\subsection{Type of Research}

Descriptive research design has been used in the study.

\subsection{Sample Size}

ET'S who have undergone the Training process of one year in NPTI, Faridabad. The total no of ET's were 127.

\subsection{Company}

Power grid Corporation of India Limited.

\subsection{Methods of Data Collection}

The primary data has been collected through Questionnaire. While the secondary data for the study has been taken from various sources like: Company Website, books, magazines and Journals, Company's Manual. 


\section{Macrothink}

\subsection{Feedback report from Executive Trainees (ET)}

In order to get feedback from Executive trainees on academic aspects of their training module, a questionnaire was distributed to them for obtaining their feedback based on 21 statements on academic aspects. These statements were on Likert point scale wherein trainees were asked to provide their feedback by ticking any one of the categories ranging from Strongly Disagree to Strongly Agree (five categories). Apart from rating the statements, suggestions were also invited on addition/ deletion of topic(s) and preferred duration of class-room training and On the Job Training.

\section{Data Analysis}

The feedback reports were received from 127 Executive Trainees who have undergone classroom training at NPTI, Faridabad. The summary of mean rating for various aspects of training module is given below:

Following tables show the feedback of the questionnaire on the academic aspects of the training programme:

Table 2. Showing MEAN RATINGS of feedback on academic aspects of training

\begin{tabular}{|c|c|c|c|}
\hline S. No. & \multicolumn{2}{|l|}{ Statement } & $\begin{array}{l}\text { ET's } \\
\text { NPTI }\end{array}$ \\
\hline 1 & \multicolumn{2}{|c|}{ Duration of initial class-room training (months) was sufficient } & 4.41 \\
\hline \multirow{5}{*}{2} & \multirow{5}{*}{ Duration of following modules were sufficient } & Technical & 4.01 \\
\hline & & $\mathrm{HR}$ and $\mathrm{OB}$ & 4.44 \\
\hline & & Finance & 4.39 \\
\hline & & IT & 4.24 \\
\hline & & Contracts and Materials & 4.44 \\
\hline 3 & Depth of learning in technical module is adequate & & 4.22 \\
\hline \multirow{5}{*}{4} & \multirow{5}{*}{$\begin{array}{l}\text { Sufficient study material was provided to support } \\
\text { the instructions in the following modules }\end{array}$} & Technical & 4.13 \\
\hline & & $\mathrm{HR}$ and $\mathrm{OB}$ & 4.36 \\
\hline & & Finance & 4.35 \\
\hline & & IT & 4.26 \\
\hline & & Contracts and Materials & 4.44 \\
\hline 5 & \multicolumn{2}{|c|}{$\begin{array}{l}\text { It benefits to have a rotational OJT as against on OJT in one department (Area/ } \\
\text { Unit) }\end{array}$} & 4.46 \\
\hline 6 & \multicolumn{2}{|l|}{ My mentor/ guide was very helpful during the OJT } & 4.57 \\
\hline 7 & \multicolumn{2}{|c|}{ Post OJT second phase class-room training is helpful and necessary } & 4.63 \\
\hline
\end{tabular}


8 Out-bound self development and team building exercise was effective in 4.64 building confidence and a team

9 Study tours to the following manufacturer's sites were very useful

ABB, Baroda

4.66

CGL, Nasik

4.43

\subsection{Academic Aspects}

Table 3. Showing responses of the questionnaire on academic aspects of training

\begin{tabular}{|c|c|c|c|c|c|c|}
\hline & $\begin{array}{l}\text { Strongly } \\
\text { Disagree }\end{array}$ & Disagree & Neutral & Agree & $\begin{array}{l}\text { Strongly } \\
\text { Agree }\end{array}$ & Total \\
\hline $\begin{array}{l}\text { Duration of initial class-room training } \\
\text { ( } 4 \text { months) was sufficient }\end{array}$ & 0.00 & 0.79 & 5.51 & 45.67 & 48.03 & 100 \\
\hline $\begin{array}{l}\text { Modules Duration was Sufficient } \\
\text { (TECHNICAL) }\end{array}$ & 2.36 & 8.66 & 11.02 & 41.73 & 36.22 & 100 \\
\hline $\begin{array}{l}\text { Modules Duration was Sufficient (HR } \\
\text { and OB) }\end{array}$ & 0.00 & 0.79 & 3.94 & 45.67 & 49.61 & 100 \\
\hline $\begin{array}{l}\text { Modules Duration was } \text { Sufficient } \\
\text { (Finance) }\end{array}$ & 0.00 & 0.00 & 6.30 & 48.82 & 44.88 & 100 \\
\hline Modules Duration was Sufficient (IT) & 0.00 & 0.79 & 11.02 & 51.97 & 36.22 & 100 \\
\hline $\begin{array}{l}\text { Modules Duration was Sufficient } \\
\text { (Contracts and Materials) }\end{array}$ & 0.00 & 1.57 & 1.57 & 48.03 & 48.82 & 100 \\
\hline $\begin{array}{l}\text { Depth of learning in technical module } \\
\text { is adequate }\end{array}$ & 1.57 & 2.36 & 10.24 & 44.09 & 41.73 & 100 \\
\hline $\begin{array}{l}\text { sufficient study material was provided } \\
\text { to support the instructions in the } \\
\text { following module (Technical) }\end{array}$ & 0.79 & 9.45 & 8.66 & 38.58 & 42.52 & 100 \\
\hline $\begin{array}{l}\text { sufficient study material was provided } \\
\text { to support the instructions in the } \\
\text { following module (HR and OB) }\end{array}$ & 0.00 & 0.79 & 10.24 & 40.94 & 48.03 & 100 \\
\hline $\begin{array}{l}\text { sufficient study material was provided } \\
\text { to support the instructions in the } \\
\text { following module (Finance) }\end{array}$ & 0.00 & 0.00 & 10.24 & 44.09 & 45.67 & 100 \\
\hline $\begin{array}{l}\text { sufficient study material was provided } \\
\text { to support the instructions in the } \\
\text { following module (IT) }\end{array}$ & 0.79 & 0.79 & 11.81 & 44.88 & 41.73 & 100 \\
\hline
\end{tabular}


sufficient study material was provided to support the instructions in the following module (Contracts and 0.00 0.79 6.30 $40.94 \quad 51.97$ 100 Materials)

\begin{tabular}{|c|c|c|c|c|c|c|}
\hline $\begin{array}{l}\text { benefits to have a rotational OJT as } \\
\text { against an OJT in one department } \\
\text { (area/unit) }\end{array}$ & 0.79 & 5.51 & 3.94 & 26.77 & 62.99 & 100 \\
\hline mentor was very helpful during OJT & 0.00 & 0.79 & 3.94 & 33.07 & 62.20 & 100 \\
\hline $\begin{array}{l}\text { Post OJT second phase Cathode Ray } \\
\text { Tube (CRT) is useful and necessary }\end{array}$ & 0.00 & 0.00 & 3.94 & 29.13 & 66.93 & 100 \\
\hline $\begin{array}{l}\text { Out bound self development and team } \\
\text { building exercise was effective in } \\
\text { building confidence and a team }\end{array}$ & 0.00 & 0.00 & 2.36 & 31.50 & 66.14 & 100 \\
\hline $\begin{array}{l}\text { Study tour to following manufacturing } \\
\text { sites was very useful (Asea Brown } \\
\text { Boveri (ABB), Baroda) }\end{array}$ & 0.00 & 0.79 & 0.79 & 29.92 & 68.50 & 100 \\
\hline $\begin{array}{l}\text { Study tour to following manufacturing } \\
\text { sites was very useful (Crompton } \\
\text { Greaves Ltd. (CGL), Nasik) }\end{array}$ & 0.00 & 0.00 & 7.87 & 40.94 & 51.18 & 100 \\
\hline
\end{tabular}

\section{Findings}

Major findings and issues necessitating action for enhancing training effectiveness are:

93.70\% ETs are of the view that initial class room training is sufficient. $96.06 \%$ of them are of the view that the post OJT second phase class room training is constructive and indispensable. $89.76 \%$ ETs said that the rotational OJT is valuable. $77.95 \%$ ETs said that duration of Technical module is adequate while $95.28 \%$ and $96.85 \%$ ETs were of in view that the duration of HR and OB module and Contracts and Materials modules respectively is sufficient. This clearly answers the first objective which was to analyze the efficiency of the training programme.

A large number of ETs are of the view that the study material was provided to them was good and up to the mark, whereas the marginal number of ETs have viewed that the study material was not sufficient particularly for Technical and IT. Depth of learning in technical module is reported to be average. Thus a review of the delivery including faculty viz-a-viz module and course content will be necessary to determine the gaps for remedial action before the induction of next batch. This answers the second objective which was to suggest the scope of improvements in the training programme in order to make it more effective. 


\section{Limitations}

Module should be updated on the yearly basis. The period of training should be less than one year. There should be more industry visits on time to time basis.

\section{Conclusions}

With the need to equip the trainees with organization culture/ dynamics, functional, project management, attitudinal, report writing and decision making skills to perform effectively on absorption the training plan is being worked out for the ensuring ETs batch.

\section{Recommendations}

As per the feedback of the questionnaire following topics/ subjects should be added in the training programme in order to make it more effective for the organization: details of schemes of the protection, more IT based topics should be added (Encryption, Security and Web Technology), system stability, management lectures on motivation, team building by external faculties, substation automation, more technical based modules should be added, industrial visit should be at least for two days or more, operating characteristic of numerical relays, formation, classification and standard field quality plan for construction sites, more session should be there in transmission line design, a session on how as a power grid employees deal regarding sorting out ROW, compensating problems, a separate session should be conducted for process involved in land acquisition, remedies or case studies about ROW problems, on OJT one guide should be there, study material should be improved, more session about MS Excel should be conducted, one week separate doubt clearing session is required, in advanced technology module, concentrate two days each on $765 \mathrm{KV}, 1200 \mathrm{KV} \pm$ $800 \mathrm{KV}$ systems should be added, rights and duties of power grid employees should be taught, testing and commission of $\mathrm{S} / \mathrm{S}$. 76s/400/220, a training program on auto-cad to be included in module, more duration is required to cover contract management module, more case studies to be added, advanced topics on facts devices should be there, transformer vacuuming, oil filing and dry out process, some classes should be added directly from manufacturers (BHEL, CGL, BPL and AREVA), instead of presentation of hard copy, a good write up should be given, sequential and topic elaboration, fifteen (15) days class should be conducted for telecom, training regarding Tejas and Tellabs equipments should be given, networking knowledge about routers should be given, a session for VLANS and Ethernet should be added, networking fundamentally related to POWERTEL, after OJT 4 days class for ROW, legal and DOP should be conducted, some sessions on MS-project or prime AVERA for ET (civil), for civil engineers, classes should be organized for material FQP, class on structural analysis software like STAAD pro, foundation design of equipments and tower, more emphasis on case studies and analytical discussion should be given, relay testing and testing of different type of relay used in power grid should be included in class room training, some practice for paper works should be done in power grid, at least one visit related to Telecom should be planned, single line diagram study should be done before OJT, after OJT for civil students separate classes should be organized as per core subject clarification, after OJT one day class should be arranged by HRD department. For query about employee benefits. 


\section{Macrothink

As per the feedback of the questionnaire following topics/ subjects should be deleted from the training programme in order to make it more effective for the organization: for ET (Electrical) the module of Telecom and LD and C may cut short, overlapping of the lectures should be deleted, and lastly OS for Civil Engineering should be deleted.

\section{References}

Baum, T. (1991). Management Trainees in the Hotel Industry: What Do Managers Expect?. Journal of European Industrial Training, 15, 2. https://doi.org/10.1108/03090599110135202

Coates, J. (1990). Management Training In Developing Countries. Industrial and Commercial Training, 22, 4. https://doi.org/10.1108/00197859010006473

Dana, L. P. (2001). The education and training of entrepreneurs in Asia. Education + Training, 43(8/9), 405-416. https://doi.org/10.1108/EUM0000000006486

Fullerton, R. A. (2011). Historical methodology: the perspective of a professionally trained historian turned marketer. Journal of Historical Research in Marketing, 3(4), 436-448. https://doi.org/10.1108/17557501111183608

Malik, A. (2009). Training drivers, competitive strategy and clients' needs: Case studies of three business process outsourcing organizations. Journal of European Industrial Training, 33, 2, 160-177. https://doi.org/10.1108/03090590910939058

Pillania, R. (2014). Green management: The state of practice, research, teaching, training and consultancy in Indian business schools. Journal of Management Development, 33(2), 131-148. https://doi.org/10.1108/JMD-12-2013-0157

Tsang, M. C. (1999). The cost of vocational training. Education + Training, 41(2), 79-97.

Wiese, A. (2006). Transformation in the South African chartered accountancy profession since 2001: A study of the progress and the obstacles black trainee accountants still encounter. Meditari Accountancy Research, 14(2), 151-167. https://doi.org/10.1108/ 10222529200600018

\section{Copyrights}

Copyright for this article is retained by the author(s), with first publication rights granted to the journal.

This is an open-access article distributed under the terms and conditions of the Creative Commons Attribution license (http://creativecommons.org/licenses/by/4.0/) 